\title{
Contracting In Healthcare
}

\author{
Abas Khan ${ }^{1}$ and Mohd Sarwar Mir*2 \\ ${ }^{1}$ Senior Resident, Department of Hospital Administration, Sher-i-Kashmir Institute of Medical Sciences, Srinagar, India \\ ${ }^{2}$ Resident Medical Officer, SKIMS, India
}

*Corresponding author: Mohd Sarwar Mir, Resident Medical Officer, SKIMS, India

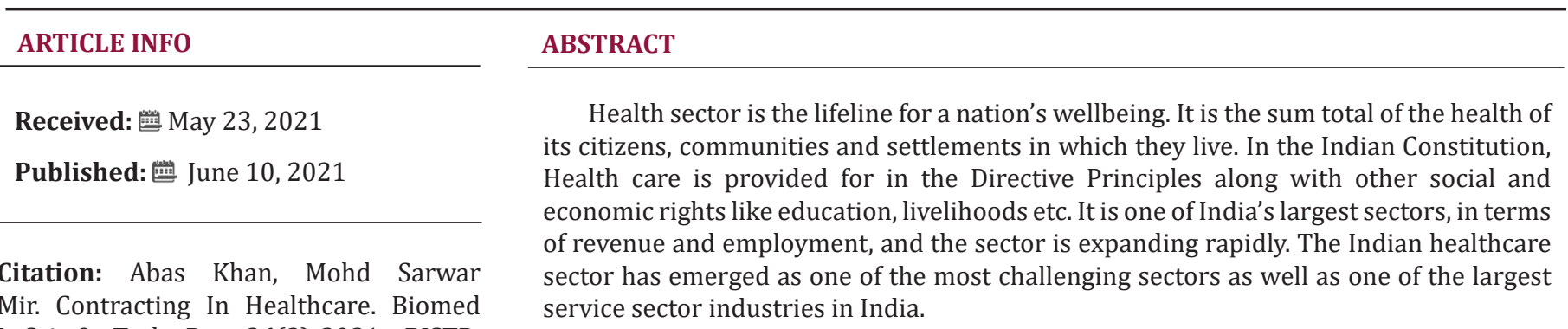

J Sci \& Tech Res 36(3)-2021. BISTR. MS.ID.005846.

Keywords: Collaboration; Competition; Public Private Partnership; Outsourcing

\section{Contracting in Health care}

Contract management is a general concept that may encompass a wide range of operational, strategic and administrative components. This variation may include differences in management goals, array of services provided, specialty emphasis, depth of management experience and centralization of decision making in the management organization. Contracting in health care is diverse in terms of the types of actors that use it, the types of contractual relationships that are established and the purpose thereof. However, one must never lose sight of the fact that contracting is a tool that should be evaluated on the basis of its impact on the performance of a health system and on peoples' health. Contracting should not be reduced to a mere management tool used to cut health costs. It is an approach that should lead the various actors to offer to the public health services that are increasingly efficient, effective, superior and fair [1,2].

To ensure that contracting is used strategically to introduce market mechanisms while ensuring that essential public services are provided and the needs of poor and vulnerable are protected, the government needs to recognize that contracting is a powerful process, a purposeful methodology not just a cluster of independent transactions. This means that contracting initiatives must be regulated and monitored at the highest level of government by experienced and astute policy makers, economists and operational personnel. In fact, despite contracting limitations, there are some issues to be considered: The first is the provider payment mechanism, second, the nature of provider and the type of contract and finally, the impact of factors outside the contract itself. Contracting with non-governmental entities will provide better results than government provision of the same services. Contracting initiatives must be regulated and monitored at the highest level of government by experienced and astute policy makers, economists and operational personnel [3-6].

\section{Private Public Partnerships}

\section{Background}

Health is the critical sector for achieving overall equitable human development in the country. India's health spending (4.1\% of GDP) is much lower than the spending of Organization for Economic Co-operation and Development (OECD) member countries. The private sector can bridge the investment deficit and improve the efficiency and outreach of service delivery.

Several constraints exist in the health sector in India. The major challenges for the health sector include

a) Accessibility and coverage in rural areas,

b) Ineffective management of existing infrastructure, 
c) Inadequate number and quality of health care professionals.

\section{Definition of Public Private Partnership (PPP)}

PPP broadly refers to long-term, contractual partnerships between public and private sector agencies, specially targeted towards financing, designing, implementing and operating infrastructure facilities to provide services that were traditionally provided by the public sector.

\section{Key Areas}

Partnership between the public and the private sector for a common goal is not a new concept or practice used globally. The role of public private partnerships can be vita.

a) Infrastructure Development - Development and strengthening of healthcare infrastructure that is evenly distributed geographically and at all levels of care.

b) Management and Operations - Management and operation of healthcare facilities for technical efficiency, operational economy and quality

c) Capacity Building and Training - Capacity building for formal, informal and continuing education of professional, para-professional and ancillary staff engaged in the delivery of healthcare.

d) Financing Mechanism - Creation of voluntary as well as mandated third-party financing mechanisms.

e) IT Infrastructure - Establishment of national and regional IT backbones and health data repositories for ready access to clinical information.

f) Materials Management - Development of a maintenance and supply chain for ready availability of serviceable equipment and appliances.

\section{Tenets of Successful Public Private Partnership}

a) Transparency: All the processes of selecting, designing, costing and awarding contract to an individual or agency for partnership should be transparent. Monitoring of its implementation and its outcome should also be transparent and information should be available to the people immediately.

b) Impartiality between public and private sectors: A PPP project should be designed and implemented with utmost concern that it does not compromise public health priorities. If not done carefully it will weaken the public sector's capacity to uphold regulations. If there is any shift with a bias for private against public health sector under the guise of partnerships, there is a danger of displacing the marginalized and may therefore be in conflict with the fundamental concept of equity in healthcare.

c) PPP as a part of social responsibility of the public sector: PPP does not mean renouncing of responsibility by the public health sector. Failure of the state in such partnerships may result in a laissez-faire attitude, prejudicial to the civil society particularly the interest of the vulnerable groups.

d) Value for money: After all, it is public money which is spent for providing public goods/services and so whether it is for or not-for-profit, it should be reasonably good both in content and its quality for the money spent. There were gaps found in good quality services at reasonably high cost in its economic sustainability. A low cost, good quality model is designed and implemented on BOT (Build-Operate-Transfer) mode. However, its post transfer O\&M (operating and maintenance) costs are not included. This makes it a 'no value for money' project and hence it can become socially useless. The costing of a project should be able to balance between its current investment and its long-term cost and needs.

e) Integration of healthcare services: The purpose of PPP is to have a team approach with public health sector, private health sector and the civil society as key players to achieve a common goal of building up a universally accessible and affordable healthcare system. Any PPP project must ensure that competition and conflict of interests does not lead to further fragmentation of an already weak healthcare system. No doubt, the project must be designed in a way that it is mutually rewarding - economically as well as socially.

f) Financially workable: Integrated projects can be cost cutters, can be for or not-for-profit but never the less require a steady cash flow. Sharing costs, partial contribution or margin money etc. is just an assurance about the financial capacity of the contracted agency. But any pinch in amount, time or pace of cash flow undermines the partnership. Cutting corners reduces both its quality and its long term sustainability.

g) Fiscal clarity: NRHM (National Rural Health Mission) is in a way large scale PPP between Government of India and the State NRHM Society. It appears on Central Government budget but not on State Government budget.

\section{Role the Government}

The government needs to take specific policy initiatives for increasing private sector interest and participation, such as:

a) Support in infrastructure set-up especially land acquisition or providing space

b) Offer capital and/or revenue grant e.g. viability gap funding 
c) Budgetary provisions for capital and operating expenses of the PPP

d) Formulate health sector specific policies and guidelines for PPP

e) Capacity building within government for managing PPP projects f) Ensure transparent and fair bidding process

g) Buy-back a share of capacity for government identified beneficiaries

\section{Models of Public Private Partnership}

Table 1.

Table 1.

\begin{tabular}{|c|c|c|c|}
\hline Models of PPP & Explanation & Advantages & Limitations \\
\hline \multirow{3}{*}{$\begin{array}{l}\text { Build- Own- Operate- Transfer } \\
\text { (BOOT) }\end{array}$} & \multirow{3}{*}{$\begin{array}{l}\text { This model helps to figure out the } \\
\text { source of financing, carries out all } \\
\text { designs, builds the infrastructure } \\
\text { and transfer ownership to the } \\
\text { public agency. }\end{array}$} & Encourage modernism & Applicable only for large projects \\
\hline & & Focus on strengths of PPP & · High transaction costs \\
\hline & & Provide an opportunity to expertise & Time-consuming \\
\hline \multirow[b]{2}{*}{ Build- Own- Operate (BO0) } & \multirow{2}{*}{$\begin{array}{l}\text { In this model, private contractors } \\
\text { have control over profits and losses } \\
\text { generated by the facility, similar to } \\
\text { a privatization process. }\end{array}$} & Development of private agency. & \multirow[b]{2}{*}{$\begin{array}{c}\text { Lack of help from public sectors in } \\
\text { the financial crisis }\end{array}$} \\
\hline & & Promotes privatization process & \\
\hline \multirow[b]{2}{*}{$\begin{array}{l}\text { Build- Operate- Lease- Transfer } \\
\text { (BOLT) }\end{array}$} & \multirow{2}{*}{$\begin{array}{l}\text { In this model, the government gives } \\
\text { concession to a private entity to } \\
\text { build a facility and at the end of the } \\
\text { project, transfer of ownership to } \\
\text { the government. }\end{array}$} & Full authority to government & \multirow[b]{2}{*}{$\begin{array}{c}\text { Limited motivation for the private } \\
\text { sector due to the transfer of } \\
\text { ownership }\end{array}$} \\
\hline & & $\begin{array}{l}\text { Public service delivery in an } \\
\text { effective way }\end{array}$ & \\
\hline Lease -Develop -Operate (LDO) & $\begin{array}{l}\text { This model involves public owner } \\
\text { leasing facility to a private company. } \\
\text { The private company responsible } \\
\text { for maintenance and operate as per } \\
\text { specified. }\end{array}$ & $\begin{array}{l}\text { Provides a platform for the private } \\
\text { sector to perform well. }\end{array}$ & $\begin{array}{l}\text { No capital mobilized from the } \\
\text { private sector }\end{array}$ \\
\hline $\begin{array}{c}\text { Rehabilitate- Operate- Transfer } \\
\text { (ROT) }\end{array}$ & $\begin{array}{l}\text { Under this model, the governments } \\
\text { and local bodies allow the private } \\
\text { agency to rehabilitate facility } \\
\text { during concession period and } \\
\text { after the period; the project is } \\
\text { transferred back to local bodies. }\end{array}$ & $\begin{array}{l}\text { Provides rehabilitation facility to } \\
\text { private promoters. }\end{array}$ & Time restriction \\
\hline \multirow{2}{*}{$\begin{array}{l}\text { Design, Build, Finance and Operate } \\
\text { (DBFO) }\end{array}$} & \multirow{2}{*}{$\begin{array}{l}\text { In this model, the private agency } \\
\text { undertakes the responsibility for } \\
\text { the operation of the project for the } \\
\text { period of concession. }\end{array}$} & $\begin{array}{c}\text { Opens up domestic markets to } \\
\text { overseas competition }\end{array}$ & Higher cost of private capital \\
\hline & & $\begin{array}{l}\text { Brings new ideas from outside } \\
\text { public sector }\end{array}$ & Expensive procurement process \\
\hline
\end{tabular}

\section{Outsourcing}

\section{Background}

The concept of outsourcing came from the American terminology "Outside Resourcing", meaning to get resources from the outside. The term was later used in the economic terminology to indicate the use of external sources to develop the business, which typically were using their internal resources. Outsourcing is an increasingly popular strategy that healthcare organisation can use to control the rising costs of providing services. With outsourcing, an external contractor assumes responsibility for managing one or more of a healthcare organization's business, clinical, or hospitality services. Because the contractor specializes in providing a specific service and can achieve economies of scale, he/she may be able to provide a service more efficiently and less expensively than the healthcare organisation. Outsourcing services peripheral to the organization's primary operations may also enable healthcare administrators and staff to concentrate more efficiently on their organisation's core business.

\section{Common Services outsourced in Hospitals}
a) Security
b) Laundry
c) House keeping
d) Food services
e) Maintenance- civil, electrical and mechanical
f) Pharmacy
g) Transportation - ambulances, other 


\section{Emerging Areas that can be Outsourced}

- Laboratory services

- $\quad$ Radiology

- $\quad$ Nursing

- $\quad$ Biomedical engineering

- Blood bank

- $\quad$ Physiotherapy

- Homecare services

- $\quad$ Outreach services (e.g. camps)

- $\quad$ IT Services

- $\quad$ Billing

- Insurance Claims Processing

- Revenue Cycle Management

- $\quad$ Payroll processing

- $\quad$ Marketing

- $\quad$ HR Processes

\section{Outsourcing Decision-Making Factors}

The number of factors affect the decision to outsource a service:
1) Cost savings
2) Customer satisfaction
3) Focus on core business
4) Lack of personnel
5) Lack of funds

\section{Impact of Outsourcing}

a. Improvement in customer satisfaction.

b. Improvement Quality of the services provided by the hospitals.

c. Cost reduction.

\section{Benefits from outsourcing}

a) Improvement in service quality levels.

b) Economies of scale.

c) Use of the external provider's infrastructure.

d) Opportunity for the healthcare organisation to focus on its core business.

e) Enhanced flexibility.

f) Accelerate the benefits reengineering. g) Sharing risks.

h) Capital injection.

\section{Difficulties in Implementation}

a) Lack of coordination and integration between the healthcare organisation and the external provider as well as the insufficient understanding of the provider about the user's operations.

b) Employees' resistance to changes.

c) Price negotiation and billing problems.

\section{Managerial Implications}

The important practical implications for those involved in outsourcing investigations in the healthcare sector. The benefits realized after the implementation of the outsourcing decision have explained the relatively high satisfaction level of the users and, hence, the increasing future trend of outsourcing. To those healthcare organisations considering outsourcing of their activities, this positive feedback should be reassuring. The number of experienced organisations provides an important source of information about how to proceed and what to expect. The most significant reasons for outsourcing are to improve customer service, to reduce costs, to enable healthcare organisations to focus on core activities, and to increase flexibility to configure resources to meet changing market needs. Some organisations do not achieve the expected benefits from outsourcing, due to lack of formal outsource decision-making process including medium-and long-term cost-benefit analyses, resistance to changes, and the inability to formulate and quantify requirements. The most significant risks of outsourcing lie in the need to develop new management competencies, capabilities and decision-making processes. These include decisions on which activities should remain within the healthcare organisation and which outsourced, whether all or part of the activity should be outsourced, and how to manage relationships rather than internal functions and processes.

Mistakes in identifying core and noncore activities can lead healthcare organisation to outsource their competitive advantages. However, what is core one day may not be so the next. Moreover, once organizational competence is lost, it is difficult to rebuild. There is a difficult decision regarding how organizational competence is lost, it is difficult to rebuild. There is a difficult decision regarding how "close to core" outsourcing should be. Failure to manage outsourcing relationships properly, perhaps through service level agreements, may reduce customer service, levels of control and contact with customers. The assessment of costs of "make or outsource" should include the additional cost burden of managing the outsource relationships. Because the introduction of contract services into an organisation represents an important shift in the way in which business is conducted, the provision of appropriate 
training for employees is an important issue. The training efforts should typically focus on employees' ability to adjust into another environment and new roles. This includes use of computerized systems, higher skills/knowledge development, and systems support. Once the decision to outsource is accepted, there is little resistance to change by the employees.

\section{References}

1. Aalders R (2001) The IT Outsourcing Guide. John Wiley \& Sons, Ltd. Chichester, pp. 244

2. Baldwin LP, Irani Z, Love PE (2001) Outsourcing information systems: drawing lessons from a banking case study". European Journal of Information Systems 10(1): 15-24.

\section{ISSN: 2574-1241}

DOI: 10.26717/BJSTR.2021.36.005846

Mohd Sarwar Mir. Biomed J Sci \& Tech Res

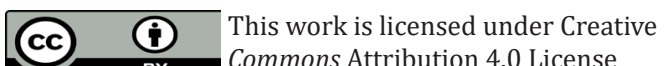

Submission Link: https://biomedres.us/submit-manuscript.php
3. Currie W (1998) Using multiple suppliers to mitigate the risk of IT outsourcing at ICI and Wessex Water. Journal of Information Technology 13(3).

4. Gillespie MH, Matthews JR (2002) Service Providers. ASPs, ISPs, MSPs, and WSPs, John Wiley \& Sons, Inc, New York.

5. Hirschheim R, Lacity M (2000) The Myths and Realities of Information Technology Insourcing. Communications of the ACM 43(2): 99-107.

6. Lacity M (2000) Lessons in Global Information Technology Sourcing. IEEE Computer 35(8): 23.

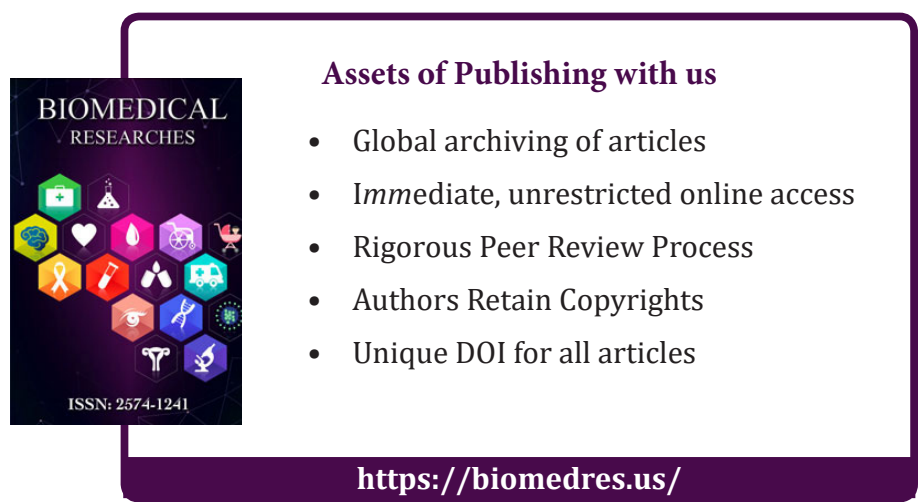

